The International Journal of Banking and Finance, Volume 10 (Number 1), 2013: Pages 134-146

\title{
THE RELATIONSHIP BETWEEN RISK PROPENSITY, RISK PERCEPTION AND RISK-TAKING BEHAVIOUR IN AN EMERGING MARKET
}

\author{
Fazelina Sahul Hamid $^{\mathrm{a}}$, Gary John Rangel ${ }^{\mathrm{b}}$, Fauziah M. Taib ${ }^{\mathrm{a}}$, and Ramayah Thurasamy ${ }^{\mathrm{a}}$ \\ ${ }^{a}$ Universiti Sains Malaysia and ${ }^{\mathrm{b}}$ Monash University Malaysia
}

\begin{abstract}
This paper reports evidence to support a relationship between risk propensity, risk perception, and risk-taking behaviour of investors in an emerging market. Primary data were gathered using a validated structured questionnaire, which was self-administered by respondents: there were 162 investors from 8 stockbroking companies. A multiple regression was used to test the direct and indirect effects of the identified behavioural characteristics on investment decision. Risk propensity was found to be positively related to risk-taking behaviour whereas risk perception was negatively related to risk-taking behaviour. It was further found that risk perception partially mediates the effect of propensity to take risk. This suggests that the perceptual framing of a situational context in the investors' thought processes reduces but it does not totally overwhelm the innate personality traits with respect to either the investor's risk-seeking or risk-averseness. The tendency to engage in risky behaviour is more psychological in nature. The implications of the research are further explored.
\end{abstract}

Keywords: risk propensity, risk perception, risk-taking behaviour, empirical study

JEL classification: D81, G02.

\section{Introduction}

Malaysia’s benchmark Kuala Lumpur Composite Index (KLCI) reached an all-time high of $1,872.52$ points in December 2013. The previous high coincided with the super bull-run of 1993 when the KLCI value was 1,275.30. However, the circumstances now and then seem to be different. Retail investors who made up 60 per cent to 70 per cent of the daily trading volume during the super bull-run have not returned in droves this time around. In fact, retail investors have continually shunned the stock market since the losses retail investors took during the 1997 Asian Financial Crisis as well as during the 2008 subprime crisis. The nations's Prime Minister declared in March 2010 that the state-controlled Employees Provident Fund (EPF) accounted for 
50 per cent of the daily trading volume in the equity and bond markets with most individual investors shifting to mutual funds after the Malaysian economy slid into a recession in 1998 (Chan, 2010). Retail investors are still wary of trading on the market because they are not convinced that Malaysia's economic recovery is real and sustaining. Moreover, their appetite for risk seems to have abated (Chieh, 2010).

Therefore, the objective of this paper is to understand the current risk-taking behaviour of the Malaysian retail investors. It seeks to understand whether risk aversion is indeed a significant contributing factor to the lack of participation in the local stock market. By examining the risktaking behaviour of retail investors, it would help in identifying the salient factors that influence investors to participate less in the Malaysian stock market. We use a model developed for exploring risk-taking behaviour in the corporate context and apply it to individual investors' trading behaviour. It is posited that risk perception and risk propensity have a significant influence on risk-taking behaviour. We also posit that retail investors' risk perception may have a mediating effect on risk propensity (i.e., the willingness to take risks).

The rest of the paper is organised in the following manner. The next section provides a discussion of risk-taking behaviour and the factors that could relate to it. Section 3 describes the relationship, develops the hypotheses and the methodology to test the relationship. Section 4 is a discussion of the data and summary of empirical results. The conclusion in Section 5 completes the paper.

\section{Literature Review}

Although risk-taking behaviour is a widely researched topic in finance, a search of empirical literature show that consumer decision-making research in the context of financial products is surprisingly scarce (Byrne, 2005). Past research on risky decision-making has focused on individual risk-taking behaviour in an organisational context especially in management decisionmaking. There is a dearth of decision-making studies in the context of the securities market in general and none exists from an emerging economy in particular. As such, this paper seeks to address a gap in literature.

Traditional theories, some of which have won Nobel accolades, have classified financial risk as something quantifiable, so it is measured by the volatility of returns and individual trade-off between risk and return (Diacon, 2004). This is the essence of the expected utility model proposed by von Neumann \& Morgenstern (1944). The axioms of the utility theory argue that investors are (1) completely rational, (2) able to deal with complex choices, (3) risk-averse, and 
(4) wealth maximising agents. This assumes that investors select a portfolio that maximises their returns while minimising their risks. The utility theory is also the central tenet of the efficient market hypothesis with its concept of investor rationality. Ibrahim \& Lim (1995), however, found this relationship to be unstable, as has also been shown by recent studies. Most retail investors speculate in a bullish market but revert toward fundamental analysis in a bearish market. However, an updated study by Lai, Low, \& Lai (2001) found Malaysian retail investors to exhibit stable rational behaviour.

These contradictory findings lead us to believe there may be behavioural explanations with regard to retail investors' stock market participation: this is exactly what the Momentum Theory explains. Proponents of behavioural finance argue investors may not be rational at all times. Kahneman \& Tversky (1979) proposed the prospect theory as an alternative to the expected utility theory. It is one of the most widely used theories of individual decision-making that looks at the cognitive limitation of the decision-makers. Specifically, they argue that individuals will be risk-averse in a gain situation and risk-seeking in a loss situation. In reviewing the prospect theory, Sitkin \& Pablo (1992) found contradictions where past success led to the willingness to engage in risky behaviour and they proposed an alternative model of the determinants of risky behaviour. They suggested that risky behaviour is determined by two individual factors, namely risk propensity and risk perception. They further postulated that the relationship between risk propensity and risk behaviour is mediated by risk perception described in Figure 1 below.

\section{Figure 1: Proposed Research Model}

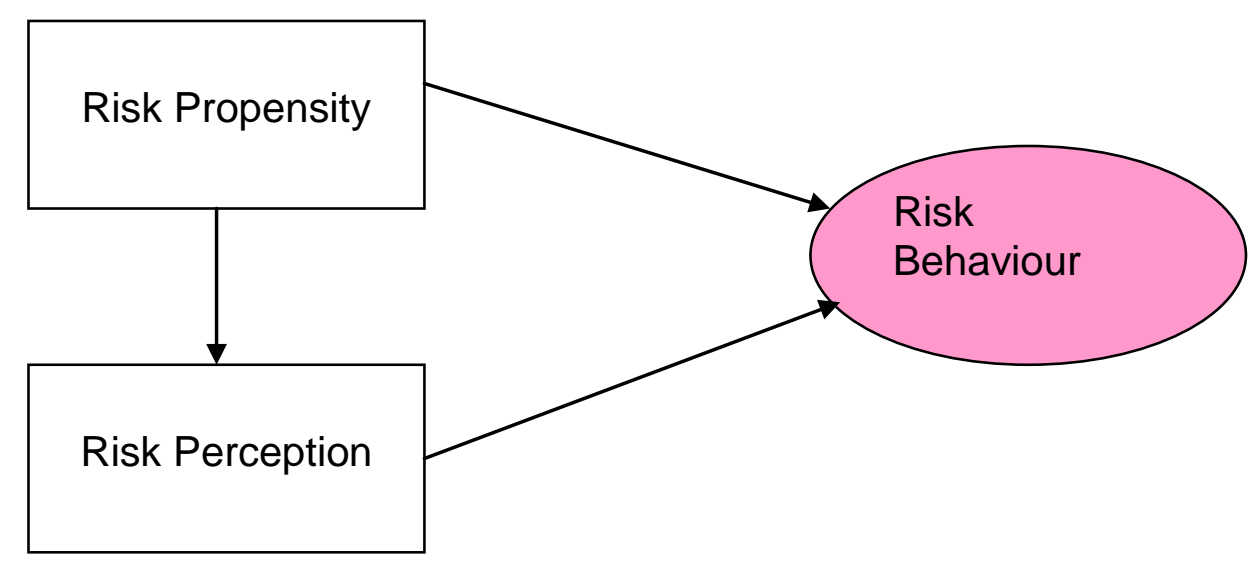

Risk perception is defined as an individual's assessment of the inherent risk in a given situational problem (Sitkin \& Wiengart, 1995). This assessment is based on one's probabilistic estimation of the degree of uncertainty, controllability, and confidence in a problematic situation. Risk perception is likely to be affected by cognitive biases that arise out of ways of thinking 
known as heuristics (Diacon, 2004). This acts as a shortcut to enable processing and simplification of information. The disposition effect postulated by the Prospect Theory is consistent with a negative relationship between risk perception and risk-taking behaviour. Positive gain situations lead to conservative, risk-averse behaviour whereas situations labelled as negative elicit risk-seeking behaviour. Some studies in the literature have reported the opposite results. One example is the threat-rigidity hypothesis postulated by Staw, Sandelands, \& Dutton (1981). They found that, under threatening situations, individuals tend to rely heavily on prior expectations, have increased attention to dominant cues, and are inclined to emit well-learned responses which are all consistent with conservative, risk-averse behaviour. In positively labelled contexts, others have also reached opposite conclusions concerning the Prospect Theory. March \& Shapira (1987) and Thaler \& Johnson (1990) suggest that, when conditions are perceived positively, individuals tend to focus on opportunities inherent in those situations and thus will be inclined to behave in a risk-seeking manner as a result of their past successes. The argument here is not for an absence of a relationship between risk perception and risk behaviour but the sign of the relationship.

Figure 2: Juxtaposing Extant Theoretical Models and Predictions of Risk Behaviour

\begin{tabular}{|c|c|c|c|}
\hline & & $\begin{array}{l}\text { Situational Chara } \\
\text { (Objective or Per }\end{array}$ & $\begin{array}{l}\text { eristics } \\
\text { ived) }\end{array}$ \\
\hline & & Positive & egative \\
\hline & $\begin{array}{l}\text { Risk- } \\
\text { Averse }\end{array}$ & $\begin{array}{l}\text { Prospect Theory - } \\
\text { Conservation of Prior Gains } \\
\text { (Kahneman \& Tversky,1979) } \\
\text { Loss Prevention Bias } \\
\text { (Jackson \& Dutton, 1988) } \\
\text { Prediction: Low Risk } \\
\text { Behaviour } \\
\text { Cell } 1\end{array}$ & $\begin{array}{l}\text { Threat Rigidity } \\
\text { (Staw, Sandelands, \& } \\
\text { Dutton, 1981) } \\
\text { Hypervigilance } \\
\text { (Janis \& Mann, 1977) } \\
\text { Prediction: Low Risk } \\
\text { Behaviour } \\
\text { Cell } 2\end{array}$ \\
\hline 1 10pensily & & $\begin{array}{l}\text { Attention to } \\
\text { Opportunities } \\
\text { (March \& Shapira, 1987) }\end{array}$ & $\begin{array}{l}\text { Prospect Theory - } \\
\text { Going for Broke } \\
\text { Kahneman \& Tversky } \\
\text { 1979; Singh, 1986) }\end{array}$ \\
\hline & $\begin{array}{l}\text { Risk- } \\
\text { Seeking }\end{array}$ & $\begin{array}{l}\text { Prediction: High } \\
\text { Risk Behaviour } \\
\text { Cell } 3\end{array}$ & $\begin{array}{l}\text { Prediction: High } \\
\text { Risk Behaviour } \\
\text { Cell } 4\end{array}$ \\
\hline
\end{tabular}


One way to reconcile these apparent contradictory findings, instead of accepting one and rejecting the other, is the identification of previously latent variables which may help explain the contradictory results. There are two possible scenarios that such a relationship could occur. First, risk perception-to-risk-behaviour relationship is moderated by a hidden variable that modifies the relationship between perception of risk and risky behaviour. Second, risk perceptions may be correlated with some previously unexamined variable that is actually driving the relationship. Sitkin \& Pablo (1992) made the case that missing variable is risk propensity. In order to reconcile the mixed results, we illustrate them in Figure 2 by forming a matrix between risk propensity (risk-averse behaviour versus risk-seeking behaviour) with risk perceptions (positive situation versus negative situation). Quadrants 1 and 4 are consistent with the Prospect Theory where risk-averse investors are prone to exhibit low-risk behaviour in circumstances of low perceived risk (Quadrant 1) and vice versa (Quadrant 4). Quadrants 2 and 3 are consistent with its competing alternatives. Nevertheless, it can be argued that the settings in which the studies that fall in these two quadrants would determine the results obtained. Specifically, studies in Quadrant 2 is meant to examine more bureaucratic, risk-averse contexts (Janis \& Mann, 1977; Staw, Sandelands, \& Dutton, 1981) and studies in Quadrant 3 focuses on more entrepreneurial situations (March \& Shapira, 1987).

Prior literature on risk propensity concentrates on two main aspects. The first relates to individual investors' differences that influence risk-taking behaviour. The second aspect relates to the situational influence. As a result, there are also contradictory opinions on risk propensity (Huff, Keil, Kappelman, \& Prybutok, 1997). One school of thought would argue that risk propensity is a trait that is stable over time (Gerrans, Faff, \& Hartnett, 2012) while another school of thought is that it is a trait that changes through a learning process. Prior research on the influence of personality on risk-taking behaviour argues that risk propensity is determined by individual characteristics. For example, personality traits such as impulsivity, sensation-seeking, and low self-control generally exhibit risk-taking behaviour (Mishra \& Lalumière, 2011).

Prior studies have also shown that personality constructs, especially risk-taking, becomes a consistent and emergent factor in decision-making within the positive domain whereas in negative domains, personality constructs associated with risk becomes diminished and are less of a factor in decision-making (Skeel, Neudecker, Pilarski, \& Pytlak, 2007; Garvey, 2010). This confirms the findings of Masters (1989) who found through the Choice Dilemmas Questionnaire (CDQ) that risk-taking investors display more risk-prone CDQ scores.

The review of past research as summarised in Figure 2 does suggest an interaction effect between risk propensity and risk behaviour. The main effect of risk propensity on risk behaviour 
might well be strengthened as the level of perceived risk rises. Investors, who are risk-averse, will exhibit such behaviour if their perceived situational risk rises. Conversely, investors who are risk-seeking are more prone in exhibiting such behaviour the higher the perceived risk (Sitkin \& Wiengart, 1995).

\section{A. The relationship}

The description by MacCrimmon \& Wehrung (1986) of risk propensity as a "willingness to take risks" clearly indicates that this willingness will eventually affect actual risk-taking. Individual tendency to take or avoid risks has been shown to affect risk-taking (Brockhaus, 1980). Thus, this study proposes that:

H1: Risk propensity will be positively related to risk-taking behaviour.

H2: The effect of risk propensity on risk behaviour will be mediated by risk perception

Individuals who perceive higher levels of risk in a problematic situation relate risks with negative outcomes and thus will make less risky decisions. Individuals, who perceive lower levels of risk, will relate it with positive outcomes thus making more risky decisions (Sitkin \& Wiengart, 1995). In line with this, it is hypothesised that:

H3: Risk perception will be negatively related to risk-taking behaviour.

\section{Methodology}

The unit of analysis for this paper is the individual investors as they are major players in the stock market. The operational definitions of the variables used are summarised in Table 1. The questionnaire used was adopted from Sitkin \& Pablo (1992) with modification to suit the context of this study.

The questionnaire was administered to individual investors who frequented the public galleries of eight stockbroking companies. The questionnaire focuses on a typical investment scenario faced by investors. Two sets were developed to depict a situation in a positive scenario and a negative scenario respectively. One hundred questionnaires for each scenario were distributed. Only individuals who have had experience in investing in the stock market were interviewed. A total of 177 completed questionnaires were returned (response rate $=88.5 \%$ ) and 
out of these, 15 were removed due to incompleteness or inconsistencies in the responses. Of the remaining 162 questionnaires, 89 and 73 were positive and negative scenario versions respectively.

Table 1: Operational Definitions of Variables

\begin{tabular}{|c|c|c|}
\hline Variables & Operational Definition & Prior studies \\
\hline Risk behaviour & $\begin{array}{l}\text { Degree of uncertainty associated } \\
\text { with the chosen decision } \\
\text { outcome (certain outcome vs. } \\
\text { probable outcome) }\end{array}$ & $\begin{array}{l}\text { Kahneman \& Tversky (1979) } \\
\text { Sitkin \& Pablo (1992) } \\
\text { Sitkin \& Weingart (1995) } \\
\text { Pablo (1997) }\end{array}$ \\
\hline Risk propensity & $\begin{array}{l}\text { Individuals' current period } \\
\text { tendency toward risk-taking }\end{array}$ & $\begin{array}{l}\text { MacCrimmon \& Wehrung (1986) } \\
\text { Sitkin \& Pablo (1992) } \\
\text { Sitkin \& Weingart (1995) } \\
\text { Pablo (1997) } \\
\text { Wong (2005) }\end{array}$ \\
\hline Risk perception & $\begin{array}{l}\text { Individuals' assessment of the } \\
\text { degree of risk inherent in a } \\
\text { decision situation }\end{array}$ & $\begin{array}{l}\text { Sitkin \& Pablo (1992) } \\
\text { Sitkin \& Weingart (1995) }\end{array}$ \\
\hline
\end{tabular}

\section{Results}

Table 2: Personal Profile of the Respondents

\begin{tabular}{llcc}
\hline Profile & Description & Total & Percentage \\
\hline Gender & Male & 93 & 58 \\
Age & Female & 67 & 42 \\
& Below 20 years old & 2 & 1 \\
& $21-30$ years old & 19 & 12 \\
& $31-40$ years old & 79 & 49 \\
\multirow{4}{*}{ Race } & 41-50 years old & 42 & 26 \\
& Above 50 years old & 20 & 12 \\
& Malay & 56 & 35 \\
\multirow{3}{*}{ Education } & Chinese & 92 & 57 \\
\multirow{4}{*}{ Level } & Indian & 14 & 9 \\
& Others & 0 & 0 \\
& SPM or lower & 28 & 17 \\
Average & Certificate & 55 & 34 \\
Investment & Diploma & 40 & 25 \\
Amount & Bachelor's Degree & 31 & 19 \\
\hline
\end{tabular}


The profile of the respondents is presented in Table 2. The frequency analysis shows that 58.1 per cent of those sampled were male. Almost half of the investors belong to 31-40 years age group. Approximately 60 per cent of the cohort was Chinese. About half of the investors had ten years of education with a certificate or had lower educational qualifications. About 58 per cent of the investors invested less than RM10,000 (US\$3,400) in the stock market.

\section{A. Goodness of measures}

We establish the goodness of fit measures. Two of the tests are validity and reliability. Although there are various measures of validity and reliability, we have opted for construct validity and the inter-item consistency measures for this paper.

Factor analysis is a data reduction technique that purports to reduce a number of items into a manageable number of factors (see Table 3). It basically tests the factor validity of the measures. We used a factor analysis with a Varimax rotation to validate the 10 items used to measure risk perception and risk propensity. The factor analysis yielded a 2 -factor solution explaining 76 per cent of the variation with a significant test value using Bartlett's test of sphericity $\left(\chi^{2}=501.145\right.$, $\mathrm{p}<0.01)$. The Kaiser Meyer Olkin's measure of sampling adequacy was 0.70 , which can be described as moderate based on Harris and Woodward's (1974) classification. Thus, we can conclude that the factors are distinct and valid.

Table 3: Component Analysis for Mediating Variables

\begin{tabular}{lcc}
\hline & \multicolumn{3}{c}{ Components } \\
\hline Items & 1 & 2 \\
\hline Risk Perception 1 & $\mathbf{0 . 8 8 0}$ & -0.103 \\
Risk Perception 3 & $\mathbf{0 . 8 7 4}$ & -0.024 \\
Risk Perception 5 & $\mathbf{0 . 6 0 3}$ & 0.074 \\
Risk Perception 7 & $\mathbf{0 . 9 2 7}$ & -0.118 \\
Risk Propensity 1 & 0.026 & $\mathbf{0 . 9 4 0}$ \\
Risk Propensity 2 & -0.097 & $\mathbf{0 . 9 3 5}$ \\
\hline Eigenvalue & 2.771 & 1.789 \\
Variance (75.998\%) & 46.183 & 29.815 \\
\hline
\end{tabular}

Note: Risk Perception 2, 4, and 6, and Risk Propensity 3 were dropped due to low loadings.

Next, the reliability of the measures was assessed by using the Cronbach's alpha coefficient. Reliability refers to the degree of consistency, as Kerlinger (1986) puts it; if a scale possesses a high reliability, the scale is homogeneous. According to Nunnally (1978), alpha values equal to or greater than 0.70 are considered to be a sufficient. The alpha values ranged from 0.84 to 0.87 , 
and were much higher than cut-off of 0.7. Thus, we conclude that the measures have sufficient reliability. Conclusion made based on the results from the survey is acceptable. Table 4 depicts the summary of the reliability analysis.

Table 4: Summary of Reliability Analysis

\begin{tabular}{lccc}
\hline Variables & Items & Items Deleted & Cronbach's Alpha \\
\hline Risk Preference & 3 & 0 & 0.85 \\
Risk Propensity & 2 & 1 & 0.87 \\
Risk Perception & 7 & 3 & 0.84 \\
\hline
\end{tabular}

\section{B. Hypotheses testing}

A regression analysis was conducted in order to test two hypotheses. Table 5 is a summary of results. As hypothesised, risk propensity was found to be positively related $(\beta=0.296, p<0.01)$ to risk-taking behaviour whereas risk perception was negatively related $(\beta=-0.242, p<0.01)$ to risk-taking behaviour. Thus, both $\mathrm{H}_{1}$ and $\mathrm{H}_{3}$ are supported. Further to that, we also tested the mediation effect of risk perception on the risk propensity and risk-taking behaviour.

Table 5: Results of the Regression Analysis

\begin{tabular}{lcccc}
\hline & $\begin{array}{c}\text { Unstandardised } \\
\text { Beta }\end{array}$ & Standardised Beta & $t$ value & $p$ value \\
\hline Risk Propensity & 0.484 & 0.296 & 3.799 & 0.000 \\
Risk Perception & -0.384 & -0.242 & -3.110 & 0.002 \\
\hline$F$ value & \multicolumn{4}{c}{$13.354 * *$} \\
$R^{2}$ & 0.16 & \\
Adjusted $R^{2}$ & & 0.148 & \\
\hline$* * \mathrm{p}<0.01$ & & &
\end{tabular}

A mediator specifies how (or the mechanism by which) a given effect occurs (James \& Brett, 1984; Baron \& Kenny, 1986). Baron and Kenny (1986, pp. 1173, 1178)> it may be described as the following:

The generative mechanism through which the focal independent variable is able to influence the dependent variable of interest . . . (and) Mediation . . . is best done in the case of a strong relation between the predictor and criterion variable.

According to McKinnon et al. (1995), mediation is generally present when:

1. the Independent Variable (IV) significantly affects the mediator, 
2. the IV significantly affects the Dependent Variable (DV) in the absence of the mediator,

3. the mediator has a significant unique effect on the DV, and

4. the effect of the IV on the DV shrinks upon the addition of the mediator to the model.

Baron \& Kenny (1986) formulated the steps and conditions to ascertain whether full or partial mediating effects are present in a model. The beta value for risk propensity was 0.320 ( $\mathrm{p}$ $<0.01)$ when directly regressed against risk-taking behaviour. When risk perception is included as shown in Table 5 below, the beta value for risk propensity reduces to 0.296 and is still significant, which is consistent with partial mediation effect. We can thus conclude that $\mathrm{H}_{2}$ is supported, albeit partially.

\section{Conclusion}

This study considered whether investors' risk-behaviour in an emerging market (Malaysia) is influenced by two variables; risk perception and risk propensity. An additional measure included is whether risk perception mediates the effect of risk propensity on risk-behaviour. The results suggest both risk propensity and risk perception do influence an investor's risky behaviour. However, the effect of risk propensity on risky behaviour is partially mediated by risk perception. This is in line with findings of Sitkin \& Weingart (1995). Investors with tendencies to engage in risky investment have a behavioural motivation to project actual risky behaviour.

The results also indicate that risk perception is significant and is negatively related to risk behaviour. The findings are consistent with those of Kahneman \& Tversky (1979) which suggest that an individual's risk choices will be context dependent. However, the situational domain (positive or negative) the individual investor is only partially influences the relationship between personality traits which are an inherent determinant of risky behaviour. In other words, this suggests that the framing of a situational context in the investor's thought processes reduces but not totally overwhelms the innate personality traits (either risk-seeking or risk-averse).

The evidence presented is indicative that personality preferences emerge in the face of both positive and negative situations. These results reinforce a conclusion that providing more education to individual investors does not necessarily mean that they will be more risk-averse or risk-seeking. The tendency to engage in these behaviours is more psychological in nature. The resultant lack of participation of retail investors may be due to the over extension of risky investing in the stock market based on the bad experiences over the years. It is therefore 
imperative for regulatory authorities to strengthen the information dissemination infrastructure so retail investors would be better informed when making decisions on their investment and allow them to re-align their risk tendencies.

The standardisation of financial reporting should be one of the key initiatives undertaken. For example, the U.S. Securities and Exchange Commission sponsors EDGAR, a website which provides detailed information on public securities and companies that issue them (Shiller, 2008). With real-time and simplified financial reporting provided to the Malaysian Securities and Exchange Commission (SEC), retail investors would be able to obtain vital and easy-to-use information in deciding which stocks to invest that best suit their risk profile. In conclusion, better measures could be implemented to mitigate the information asymmetry experienced by retail investors.

Finally, further research on the stability of risk-taking personality traits could be carried out. This requires a longitudinal study. Future research could also look at the determinants of risk propensity, namely risk preference, inertia, and previous outcome history.

Author information: Fazelina Sahul Hamid is an economics lecturer, Universiti Sains Malaysia (USM), Email: fazelina@usm.my. Gary John Rangel is a lecturer of finance at the School of Business, Monash University Malaysia, Email: gary.rangel@monash.edu. Fauziah M. Taib is a professor and Dean, USM, Email: mfauziah@usm.my. Ramayah Thurasamy is professor at USM and Dy Dean, Email: ramayah@usm.my. The authors acknowledge with thanks the editorial review suggestions and comments as well as the useful editing of the paper by the Journal's coeditors. The authors alone are responsible for any errors.

\section{References}

Baron, R. M., \& Kenny, D. A. (1986). The moderator-mediator variable distinction in social psychological research: Conceptual, strategic, and statistical considerations. Journal of Personality and Social Psychology, 51(6), 1173-1182.

Brockhaus, S. R. H. (1980). Risk taking propensity of entrepreneurs. Academy of Management Journal, 23(3), 509-520. doi: 10.2307/255515.

Byrne, K. (2005). How do consumers evaluate risk in financial products? Journal of Financial Services Marketing, 10(1), 21-36.

Chan, T. H. (2010). Malaysia lures individual investors to market shunned since Asian crisis. Bloomberg. Retrieved September 28, 2012, from http://www.bloomberg.com/news/201006-09/malaysia-seeks-to-lure-individual-stock-traders-decade-after-asian-crisis.html

Chieh, Y. H. (2010). Ordinary Malaysians shun stock market amid stalling recovery. The Malaysian Insider. Retrieved September 28, 2012, from 
http://www.themalaysianinsider.com/business/article/ordinary-malaysians-shun-stockmarket-amid-stalling-recovery/

Diacon, S. (2004). Investment risk perceptions: Do consumers and advisers agree? The International Journal of Bank Marketing, 22(3), 180-198.

Dutton, J. E., \& Jackson, S. E. (1987). Categorizing strategic issues: Links to organizational action. Academy of Management Review, 12(1), 76-90. doi: 10.5465/amr.1987.4306483

Garvey, J. (2010). An investigation into risk propensity in bull and bear markets. Journal of Risk Research, 13(6), 789-804. doi: 10.1080/13669870903560283

Gerrans, P., Faff, R., \& Hartnett, N. (2012). Individual financial risk tolerance and the global financial crisis. doi:http://dx.doi.org/10.2139/ssrn.1990811

Harris, D. R., \& Woodward, J. A. (1974). Kaiser's little jiffy, Mark Iv for a small computer using basic Fortran IV. Educational and Psychological Measurement, 34(1), 119-120. doi: 10.1177/001316447403400116

Huff, R. A., Keil, M., Kappelman, L., \& Prybutok, V. (1997). Validation of the Sitkin-Weingart business risk propensity scale. Management Research News, 20(12), 39-48.

Ibrahim, M. I., \& Lim, C. F. (1995). Profile of individual investors in the Klang area. Capital Markets Review, 3, 1-15.

Jackson, S. E., \& Dutton, J. E. (1988). Discerning threats and opportunities. Administrative Science Quarterly, 33(3), 370-387.

James, L. R., \& Brett, J. M. (1984). Mediators, moderators, and tests for mediation. Journal of Applied Psychology, 69(2), 307-321.

Janis, I. L., \& Mann, L. (1977). Decision making: A psychological analysis of conflict, choice, and commitment. New York: Free Press.

Kahneman, D., \& Tversky, A. (1979). Prospect theory: An analysis of decision under risk. Econometrica, 47(2), 263-291.

Kerlinger, F. N. (1986). Foundations of behavioral research (3rd ed.). New York: Holt, Reinhart and Winston.

Lai, M.-M., Low, K. L. T., \& Lai, M.-L. (2001). Are Malaysian investors rational? Journal of Psychology and Financial Markets, 2(4), 210-215. doi: 10.1207/s15327760jpfm0204_5

MacCrimmon, K. R., \& Wehrung, D. A. (1984). The risk in-basket. The Journal of Business, 57(3), 367-387.

MacKinnon, D. P., Warsi, G., \& Dwyer, J. H. (1995). A simulation study of mediated effect measures. Multivariate Behavioral Research, 30(1), 41-62. doi: 10.1207/s15327906mbr3001_3

March, J. G., \& Shapira, Z. (1987). Managerial perspectives on risk and risk taking. Management Science, 33(11), 1404-1418.

Masters, R. (1989). Study examines investors' risk-taking propensities. Journal of Financial Planning, 2(3), 151.

Mishra, S., \& Lalumière, M. L. (2011). Individual differences in risk-propensity: Associations between personality and behavioral measures of risk. Personality and Individual Differences, 50(6), 869-873. doi: 10.1016/j.paid.2010.11.037

Nunnally, J. C. (1978). Psychometric theory (2nd ed.). New York: McGraw-Hill.

Pablo, A. L. (1997). Reconciling predictions of decision making under risk: Insights from a reconceptualized model of risk behaviour. Journal of Managerial Psychology, 12(1), 420.

Shiller, R. J. (2008). The subprime solution: How today's global financial crisis happened, and what to do about it. Princeton: Princeton University Press.

Singh, J. V. (1986). Performance, slack, and risk taking in organizational decision making. Academy of Management Journal, 29(3), 562-585. doi: 10.2307/256224 
Sitkin, S. B., \& Pablo, A. L. (1992). Reconceptualizing the determinants of risk behavior. Academy of Management Review, 17(1), 9-38.

Sitkin, S. B., \& Wiengart, L. R. (1995). Determinants of risky decision-making behavior: A test of the mediating role of risk perceptions and propensity. Academy of Management Journal, 38(6), 1573-1592.

Skeel, R. L., Neudecker, J., Pilarski, C., \& Pytlak, K. (2007). The utility of personality variables and behaviorally-based measures in the prediction of risk-taking behavior. Personality and Individual Differences, 43(1), 203-214. doi: 10.1016/j.paid.2006.11.025

Staw, B. M., Sandelands, L. E., \& Dutton, J. E. (1981). Threat-rigidity effects in organizational behavior: A multilevel analysis. Administrative Science Quarterly, 26, 501-524.

Thaler, R. H., \& Johnson, E. J. (1990). Gambling with house money and trying to break even: The effects of prior outcomes on risky choice. Management Science, 36(6), 643-660.

von Neumann, J., \& Morgenstern, O. (1944). Theory of games and economic behavior (First ed.). Princeton: Princeton University Press.

Wong, K. F. E. (2005). The role of risk in making decisions under escalation situations. Applied Psychology, 54(4), 584-607. doi: 10.1111/j.1464-0597.2005.00236.x. 